\title{
EVALUATION OF YIELD AND YIELD COMPONENTS IN SOME GENOTYPE OF FABA BEAN (Vicia Faba L.)
}

\author{
PAYMAN AZIZ ABDULLAH \\ Dept. of Horticulture, College of Agriculture, University of Duhok, Kurdistan Region-Iraq.
}

(Received: July 25, 2017; Accepted for publication: September 20, 2017)

\begin{abstract}
Four different genotype of faba bean with two different location were used to study ten yield parameters which were: plant high $(\mathrm{H})$, branch number $(\mathrm{BN} / \mathrm{PI})$, grain length $(\mathrm{cm})$, chlorophyll\%, low land pod high(cm) pod number plant ${ }^{-1}$ (PN/PI), grain length $(\mathrm{cm}), 100$ seed per yield $(\mathrm{gm})$, seed number pod ${ }^{-1}(\mathrm{SN} / \mathrm{P})$ and $^{-1}$ yield/plant (Y/PI). There were high significant differences were recorded for most parameters depending on the genotype and two position, which appear that Turkish verity at second location (research variety of agricultural college) recorded best value for most parameter under research.
\end{abstract}

\section{1- INTRODUCTION}

$\mathbf{F}$ aba bean (Vicia faba L.) consider one of the most important legumes for human and animals feeding(Bond et al., 1985). Faba bean is diploid plant with a relatively few number of large chromosomes $(2 \mathrm{n}=2 \mathrm{x}=12) \quad(\mathrm{Al}-$ Barri and Shataya, 2013; Basger et al., 2013 and Terzo poulos et al., 2008). The Genetic variability of Faba bean is absolutely large due to the presence of intermediate crossing system between autogamy and allogamy (Hanelt and Mettin, 1984). Many investigation were reported high variability among faba bean genotypes and variations for growth characters, yield and yield compounds (Tageldin and Mehasen, 2004).

Alghamdi (2007) carried out a research in order to determine the genetic study of six faba bean genotypes and the results revealed that the studied genotypes significantly different for all of the characters including plant high, number of pods plants ${ }^{-1}$, number of seed ${ }^{\text {plant-1 }}$, seed weight plant $^{-1}$ and seed yield.
This investigation was aimed to study the variability on growth trait, yield and its component of four Faba bean genotype (Vicia faba L. $2 \mathrm{n}=12$ ) at two different locations (field of crop college of agriculture and kamaka village) and also finding out the most acceptable genotype of faba bean adapted to the Kurdistan region. The agronomic performance for four faba bean genotype were compared in order to employ the best genotype (s) in breeding program for the betterment of new Faba bean cultivars.

\section{2- MATERIALS AND METHODS}

This investigation was holding during 20152016, at two locations (b1: first location in Kamaka village which is faraway $16 \mathrm{Km}$ from duhok governorate(Longitude $43^{\circ}, 38 \mathrm{E}$ ", Latitude $51^{\prime} 56^{\circ} \mathrm{N}$ ". and second location (b2): Fielf of crop of agricultural college /UOD.

Experimental material comprised four genotypes of Faba bean (a1: Italy..a2: Spain.. a3: Turkish and a4: Duhok).

Table (1): Temperature, Rainfall, and relative humidity during 2015/2016 growing season at both location.

\begin{tabular}{|c|c|c|c|c|c|c|c|c|}
\hline \multirow[t]{2}{*}{ Moth } & \multicolumn{2}{|c|}{ Max.Temp. $\left(\mathbf{C}^{0}\right)$} & \multicolumn{2}{|c|}{ Mni.Temp.( $\left.\mathbf{C}^{0}\right)$} & \multicolumn{2}{|c|}{ Rainfall (mm) } & \multicolumn{2}{|c|}{$\mathbf{R H}(\%)$} \\
\hline & $\mathrm{B} 1$ & $\mathrm{~B} 2$ & $\mathrm{~B} 1$ & $\mathrm{~B} 2$ & $\mathrm{~B} 1$ & $\mathrm{~B} 2$ & $\mathrm{~B} 1$ & $\mathrm{~B} 2$ \\
\hline November & 16.2 & 18.7 & 6.0 & 6.8 & 86.4 & 59.5 & 66 & 72 \\
\hline December & 10.8 & 13.5 & 1.1 & 7.2 & 92.6 & 87.0 & 65 & 74 \\
\hline January & 6.9 & 10.6 & -1.0 & 1.4 & 144.4 & 91.5 & 73 & 78 \\
\hline February & 13.8 & 16.8 & 3.9 & 4.5 & 68.8 & 39.0 & 67 & 74 \\
\hline March & 15.1 & 18.8 & 5.3 & 6.5 & 115.4 & 88.0 & 67 & 70 \\
\hline April & 22.0 & 25.6 & 9.7 & 15.8 & 51.8 & 40.5 & 53 & 56 \\
\hline May & 26.8 & 31.5 & 13.3 & 19.4 & 14.8 & 0.0 & 45 & 41 \\
\hline
\end{tabular}

B1: First location (Kamaka Village) and B2: Second location research field of college agriculture. 


\section{Experimental field:}

The seeds for four genotypes were sowing in (November 2015) by hand. Field exp. Were conducted in randomized complete block design (RCBD) with three replications. Each plot consisted of three rows with $5 \mathrm{M}$ long and distance between them $40 \mathrm{~cm}$. All agriculture operation was don during the growing season.

Estimated characters:

Nine plants for each plot were selected for estimation for all characters, plant high/cm, branch number plant ${ }^{-1}$, chlorophyll\%, pod length ${ }^{-1}$ $\mathrm{cm}$, low land pod high $\mathrm{cm}$, pod number plant ${ }^{-1}$ were first calculated before harvesting of selected plant. Selected plant were harvested by hand for measuring remaining trait which were grain length $(\mathrm{cm}), 100$ seed plant $^{-1}(\mathrm{gm})$, seed number pod ${ }^{-1}$ (gm) and yield plant ${ }^{-1}(\mathrm{gm})$.

\section{RESULTS}

Table (2): mean square from analysis of variance for growth trait, yield and its component (Vicia faba L.) crop at two locations.

\begin{tabular}{|c|c|c|c|c|c|c|c|c|c|c|c|}
\hline & d.f & $\begin{array}{l}\text { Plant } \\
\text { high cm }\end{array}$ & $\begin{array}{l}\text { Branch } \\
\text { number }\end{array}$ & $\begin{array}{l}\text { chlorophy } \\
\text { II }\end{array}$ & $\begin{array}{l}\text { Pod } \\
\text { length } \\
\text { (cm) }\end{array}$ & $\begin{array}{l}\text { Lowland } \\
\text { pod high }\end{array}$ & $\begin{array}{l}\text { Pod } \\
\text { number } \\
\text { plant }^{-1}\end{array}$ & $\begin{array}{l}\text { Grain } \\
\text { length }\end{array}$ & $\begin{array}{l}100 \\
\text { seed } \\
\text { wight } \\
\text { yield }^{-1} \\
\text { gm }\end{array}$ & $\begin{array}{l}\text { Seed } \\
\text { number } \\
\text { pod }^{-1}\end{array}$ & $\begin{array}{l}\text { Yield plant, } \\
\text { gm }\end{array}$ \\
\hline Replication & 2 & 14.445 & 2.236 & 29.660 & 6.701 & 2.625 & 1.041 & 0.025 & 0.006 & 0.656 & 0.0065 \\
\hline Genotype(G) & 3 & $185.179^{\star}$ & $4.749^{*}$ & $45.019^{* *}$ & $37.854^{* *}$ & $54.111^{* *}$ & $284.152^{* *}$ & 0.102 & 0.004 & $2.038^{\star *}$ & 0.031 \\
\hline Location(L) & 1 & $50.170^{*}$ & $145.533^{\star *}$ & 4.593 & $156.060^{\star *}$ & $16.666^{\star *}$ & $737.041^{\star *}$ & $2.281^{* *}$ & $0.081^{*}$ & 0.510 & 1.161 \\
\hline $\mathrm{GxL}$ & 3 & $62.068^{\star *}$ & 0.227 & $79.219^{\star *}$ & $14.987^{*}$ & $55.222^{* *}$ & $112.708^{* *}$ & 0.018 & 0.006 & $3.454^{\star *}$ & 0.029 \\
\hline Error & 14 & 9.488 & 1.014 & 3.287 & 3.965 & 1.005 & 4.378 & 0.487 & 0.001 & 0.311 & 0.0051 \\
\hline
\end{tabular}

$*, * *$ are significant at $\mathrm{P} \leq 0.05$ and $\mathrm{P} \leq 0.01$, respectively

From table (2) it is clearly show that genotype have significant effects for all parameters except grain length and 100 seed Wight, also location has high significant effect in most parameter expect chlorophyll and seed number and in the interaction of genotype $\mathrm{x}$ location shoot high significant at $1 \%$ from all trait and 5\% for pod length and not reached significant for the other traits.

Table (3). Clarify the effect of four genotype of faba bean (Vicia faba L.) and two location on the plant high $(\mathrm{cm})$, branch number and chlorophyll characters. It is clearly perceived that each of the Turkish variety has significant effect on increasing plant high $(99.32 \mathrm{~cm})$, Spain variety in branch number plant ${ }^{-1}$ (9.17) and Duhok variety for chlorophyll (48.98\%). For three mentioned characters second location has significant effect for increasing them.
In the interaction between genotype $\mathrm{x}$ location Turkish variety and second location leads to record maximum value for plant high $(100.97 \mathrm{~cm})$, However Spain variety and second location set best value for each of branch number/plant and chlorophyll\% (11.67 and 52.33\%) respectively. These results describe the selection expectation within these four genotype to improve the performance through breeding program (Sharifi, 2015). Also Ahmed et al., (2016) indicated that all growth parameters increased gradually by using different genotype. During harvest, plant high play important role in reducing yield loss and short genotype are more difficult to harvest mechanically than all genotype. (Magda and Shalaby 2000) and (Talaat and Abdallah, 2008). 
Table (3): Effect of four genotype of faba bean (Vicia faba L.) and two location on the plant high (cm), branch number (BN/PI) and chlorophyll characters.

\begin{tabular}{|c|c|c|c|c|c|c|c|c|c|c|}
\hline \multicolumn{4}{|c|}{ plant height $\mathrm{cm}$} & \multicolumn{4}{|c|}{ branch number } & \multicolumn{3}{|c|}{ chlorophyll\% } \\
\hline \multirow[t]{2}{*}{$\mathrm{a}$} & \multicolumn{2}{|c|}{$b$} & \multirow[t]{2}{*}{ a } & \multicolumn{3}{|c|}{$b$} & \multirow[t]{2}{*}{ a } & \multicolumn{2}{|c|}{$b$} & \multirow[t]{2}{*}{ a } \\
\hline & b1 & b2 & & $b 1$ & b2 & & & b1 & b2 & \\
\hline a1 & $82.67 \mathrm{e}$ & $89.93 \mathrm{~cd}$ & $86.30 \mathrm{~d}$ & $5.00 \mathrm{~cd}$ & $\begin{array}{c}10.43 \\
a b\end{array}$ & & $7.72 \quad b$ & $44.23 \mathrm{~d}$ & $\begin{array}{c}42.60 \\
\text { de }\end{array}$ & $43.42 \mathrm{c}$ \\
\hline a2 & $93.33 \mathrm{bc}$ & 87.00 de & $90.17 \mathrm{C}$ & $6.67 \mathrm{c}$ & 11.67 & a & $9.17 \quad \mathrm{a}$ & $40.80 \mathrm{e}$ & $52.33 \mathrm{a}$ & $46.57 b$ \\
\hline a3 & $\begin{array}{c}97.67 \\
a b \\
\end{array}$ & $100.97 \mathrm{a}$ & $99.32 \quad a$ & $5.67 \mathrm{~cd}$ & $\begin{array}{c}10.20 \\
a b\end{array}$ & & $7.93 a b$ & $45.70 \mathrm{~cd}$ & $\begin{array}{c}40.87 \\
\mathrm{e} \\
\end{array}$ & $43.28 \mathrm{c}$ \\
\hline a4 & $90.33 \mathrm{~cd}$ & $97.67 \mathrm{ab}$ & $94.00 \mathrm{~b}$ & $4.67 \mathrm{~d}$ & 9.40 & $b$ & $7.03 \mathrm{~b}$ & $49.77 a b$ & $\begin{array}{c}48.20 \\
\text { bc }\end{array}$ & $48.98 \mathrm{a}$ \\
\hline $\mathrm{b}$ & $91.00 \mathrm{~b}$ & $93.89 \quad \mathrm{a}$ & & $\begin{array}{c}5.50 \\
b\end{array}$ & 10.43 & & & $45.13 \mathrm{a}$ & $46.00 \quad a$ & \\
\hline
\end{tabular}

Table (4) Describe the effect of four genotype of faba bean (Vicia faba L.) and two location on the pod length $(\mathrm{cm})$ low land pod $(\mathrm{cm})$ and pod number plant ${ }^{-1}(\mathrm{PN} / \mathrm{PI})$ characters.

The data verify that Turkish variety has major role in rising low land pod $(20.83 \mathrm{~cm})$ and pod number plant ${ }^{-1}$ (46.83), at the same time first variety Italy recorded best results for pod length character $(23.33 \mathrm{~cm})$. Concerning the effect of location on all characters, the second location has significant effect on pod length $(22.27 \mathrm{~cm})$ and pod number plant ${ }^{-1}$ (43.58) whereas first location was superior on increasing lowland pod (17.33 $\mathrm{cm}$ ), same table show the effect of interaction of between genotype and location, the table evident that in all case second location $\left(b_{2}\right)$ has great role in all characters with Italy variety pod length $(25.33 \mathrm{~cm})$ and with Turkish variety for low land pod $(21.67 \mathrm{~cm})$ and pod number/plant $(51.67 \mathrm{~cm})$. Sadiki et al., (2002b) and Sifi et al., (2002) found that plant high has no significant variable for some Vicia faba genotype. Concerning number of seed/ pod contrast of our result founded by Daure et al., (2010) found no significant variability for some characters for 12 faba bean genotype. This parameters is depended on genotype (Sadiki et al., 2002). Similar results belonging to yield/ plant were recorded by Sadiki et al., (2002b), Daur et al., (2010) and Thalji (2009).

Table (4): Effect of four genotype of faba bean (Vicia faba L.) and two location on the pod length (cm) low land pod $(\mathrm{cm})$ and pod number/plant $(\mathrm{PN} / \mathrm{PI})$ characters.

\begin{tabular}{|c|c|c|c|c|c|c|c|c|c|}
\hline \multicolumn{4}{|c|}{ Pod length(cm) } & \multicolumn{3}{|c|}{ Low land pod high(cm) } & \multicolumn{3}{|c|}{ Pod number plant $^{-1}$} \\
\hline$a$ & $b$ & & $a$ & & & $a$ & $b$ & & $a$ \\
\hline & $\mathrm{b} 1$ & b2 & & $\mathrm{b} 1$ & $\mathrm{~b} 2$ & & b1 & $\mathrm{b} 2$ & \\
\hline $\mathrm{a} 1$ & $\begin{array}{c}21.33 \\
b c\end{array}$ & $\begin{array}{c}25.33 \\
a\end{array}$ & $\begin{array}{c}23.33 \\
a\end{array}$ & $\begin{array}{c}11.67 \\
f\end{array}$ & $16.33 \mathrm{~d}$ & $\begin{array}{c}14.00 \\
C\end{array}$ & $\begin{array}{c}37.33 \\
d\end{array}$ & $41.67 \mathrm{c}$ & $\begin{array}{c}39.50 \\
b\end{array}$ \\
\hline $\mathrm{a} 2$ & $\begin{array}{c}14.00 \\
e\end{array}$ & $\begin{array}{r}22.83 \\
a b\end{array}$ & $\begin{array}{c}18.42 \\
b\end{array}$ & $\begin{array}{c}19.67 \\
\text { bc }\end{array}$ & $10.67 \mathrm{f}$ & $\begin{array}{c}15.17 \\
\text { bc }\end{array}$ & $\begin{array}{c}27.33 \\
\mathrm{e}\end{array}$ & $\begin{array}{c}34.00 \\
d\end{array}$ & $\begin{array}{c}30.67 \\
d\end{array}$ \\
\hline a3 & $\begin{array}{c}16.33 \\
\text { de }\end{array}$ & $\begin{array}{c}22.50 \\
a b\end{array}$ & $\begin{array}{c}19.42 \\
b\end{array}$ & $\begin{array}{c}20.00 \\
a b\end{array}$ & $21.67 \mathrm{a}$ & $\begin{array}{c}20.83 \\
a\end{array}$ & $\begin{array}{c}42.00 \\
c\end{array}$ & $51.67 \mathrm{a}$ & $46.83 \mathrm{a}$ \\
\hline$\overline{\mathrm{a} 4}$ & $\begin{array}{c}17.00 \\
\text { de }\end{array}$ & $\begin{array}{c}18.40 \\
\mathrm{~cd}\end{array}$ & $\begin{array}{c}17.70 \\
b\end{array}$ & $\begin{array}{c}18.00 \\
\mathrm{~cd}\end{array}$ & $14.00 \mathrm{e}$ & $\begin{array}{c}16.00 \\
b\end{array}$ & $\begin{array}{c}23.33 \\
f\end{array}$ & $\begin{array}{c}47.00 \\
b\end{array}$ & $35.17 \mathrm{c}$ \\
\hline $\mathrm{b}$ & $\begin{array}{c}17.17 \\
b\end{array}$ & $\begin{array}{c}22.27 \\
a\end{array}$ & & $\begin{array}{c}17.33 \\
a\end{array}$ & $15.67 \mathrm{~b}$ & & $\begin{array}{c}32.50 \\
b\end{array}$ & $43.58 \mathrm{a}$ & \\
\hline
\end{tabular}


Table (5) show the effect of four genotype of faba bean (Vicia faba L.) and two location on the grain length, $100 \mathrm{seed} /$ yield $(\mathrm{gm})$, seed number pod $^{-1}$ and yield plant ${ }^{-1}(\mathrm{~kg})$ characters.

The results prove that Italy variety recorded high rate in increasing grain length $(3.07 \mathrm{~cm})$, however Turkish variety inscribe maximum value for each of seed number/pod and yield/ plant (5.67 and $0.715 \mathrm{~kg}$ ) respectively, while Duhok variety has significant effect for 100 seed/plant $(0.367$ gm).

The same table show that first location has great effect on each of grain length $(3.20 \mathrm{~cm})$ and seed number/pod (5.08), as well as second location b2 has main result for remaining characters $(0.392 \mathrm{gm}$ and $0.837 \mathrm{gm})$. But the interaction between two treatments, its clearly evidence that there were significant difference between interplay for Italy variety and first location for the grain length character $(3.37 \mathrm{~cm})$ and Duhok variety and second location for each of $100 \mathrm{seed} / \mathrm{yield}$ and yield/ plant (0.467 and 1.028 gm) respectively, and Turkish variety with first location has grait effect for seed number pod $^{-1}$ only (6.67). Also similar results for different growth characters of Faba bean founded by many researchers (Tageldin and Mehasen, 2004); (Ulukan et al., 2003); Alghamid and Ali (2004) and Alghamdi (2007).

Table (5): Effect of four genotype of faba bean (Vicia faba L.) and two location on the grain length, 100 seed yield $^{-1}$ (gm), seed number pod $^{-1}$ and yield plant $^{-1}$ (gm) characters.

\begin{tabular}{|c|c|c|c|c|c|c|c|c|c|c|c|c|}
\hline \multicolumn{4}{|c|}{ grain length $\mathrm{cm}$} & \multicolumn{3}{|c|}{100 seed yield gm } & \multicolumn{3}{|c|}{ Seed number pod $^{-1}$} & \multicolumn{3}{|c|}{ Yield plant $^{-1} \mathrm{gm}$} \\
\hline \multirow[t]{2}{*}{ a } & \multicolumn{2}{|c|}{$b$} & \multirow[t]{2}{*}{ a } & \multicolumn{2}{|c|}{$b$} & \multirow[t]{2}{*}{ a } & \multicolumn{2}{|l|}{$b$} & \multirow[t]{2}{*}{ a } & \multicolumn{2}{|c|}{ b } & \multirow[t]{2}{*}{ a } \\
\hline & b1 & b2 & & b1 & b2 & & b1 & b2 & & b1 & b2 & \\
\hline a1 & $3.37 \mathrm{a}$ & $2.77 \mathrm{bc}$ & $3.07 \mathrm{a}$ & $\begin{array}{c}0.300 \\
b c\end{array}$ & $\begin{array}{c}0.367 \\
b\end{array}$ & $\begin{array}{c}0.333 \\
\mathrm{ab} \\
\end{array}$ & $\begin{array}{c}4.33 \\
\mathrm{~cd} \\
\end{array}$ & $4.17 \mathrm{~d}$ & $4.25 \mathrm{c}$ & $\begin{array}{c}0.458 \\
d \\
\end{array}$ & $\begin{array}{c}0.817 \\
b c\end{array}$ & $\begin{array}{c}0.638 \\
a b \\
\end{array}$ \\
\hline $\mathrm{a} 2$ & $3.10 a b$ & $2.40 \mathrm{c}$ & $2.75 \mathrm{~b}$ & $\begin{array}{c}0.233 \\
\mathrm{c} \\
\end{array}$ & $\begin{array}{c}0.367 \\
b\end{array}$ & $\begin{array}{c}0.300 \\
b\end{array}$ & $4.00 \mathrm{~d}$ & $5.67 \mathrm{~b}$ & $\begin{array}{c}4.83 \\
b c\end{array}$ & $\begin{array}{c}0.380 \\
d \\
\end{array}$ & $\begin{array}{c}0.733 \\
\mathrm{c} \\
\end{array}$ & $\begin{array}{c}0.557 \\
b\end{array}$ \\
\hline a3 & $\begin{array}{c}3.23 \\
a \\
\end{array}$ & $\begin{array}{c}2.53 \\
\mathrm{C} \\
\end{array}$ & $2.88 \mathrm{ab}$ & $\begin{array}{c}0.300 \\
b c\end{array}$ & $\begin{array}{c}0.367 \\
b\end{array}$ & $\begin{array}{c}0.333 \\
a b\end{array}$ & $6.67 \mathrm{a}$ & $\begin{array}{c}4.67 \text { b- } \\
d\end{array}$ & $5.67 \mathrm{a}$ & $\begin{array}{c}0.515 \\
d \\
\end{array}$ & $\begin{array}{c}0.915 \\
\mathrm{ab}\end{array}$ & $\begin{array}{c}0.715 \\
\mathrm{a} \\
\end{array}$ \\
\hline a4 & $3.10 a b$ & $\begin{array}{c}2.63 \\
c \\
\end{array}$ & $2.87 a b$ & $\begin{array}{c}0.267 \\
\mathrm{c} \\
\end{array}$ & $\begin{array}{c}0.467 \\
\mathrm{a} \\
\end{array}$ & $\begin{array}{c}0.367 \\
\mathrm{a} \\
\end{array}$ & $\begin{array}{c}5.33 \\
b c\end{array}$ & $\begin{array}{c}4.67 \text { b- } \\
\mathrm{d}\end{array}$ & $\begin{array}{c}5.00 \\
a b\end{array}$ & $\begin{array}{c}0.380 \\
d\end{array}$ & $\begin{array}{c}1.028 \\
\mathrm{a} \\
\end{array}$ & $\begin{array}{c}0.704 \\
\mathrm{a} \\
\end{array}$ \\
\hline b & $3.20 \mathrm{a}$ & $2.58 \mathrm{~b}$ & & $\begin{array}{c}0.275 \\
b\end{array}$ & $\begin{array}{c}0.392 \\
a\end{array}$ & & $5.08 \mathrm{a}$ & $4.79 \mathrm{a}$ & & $\begin{array}{c}0.433 \\
b\end{array}$ & $\begin{array}{c}0.873 \\
a\end{array}$ & \\
\hline
\end{tabular}

\section{CONCLUSION}

These investigation clarify that there are significant differences between most characters for four genotype under study and the Turkish variety was recorded better result as compare to other remaining variety under cultivation in the field crop location of the college of Agriculture.

\section{REFERENCES}

- Ahmed. J. O.; Abdulla. A. $R$ and R. A. Mohammed (2016). Comparative on yield and its comparative on yield and its components performance and correlation in some broud bean Vicia faba L. genotype at bakrajo sulaimani. American- Eurasion J. Agric. And Environ. Sci., 16 (3):635-640.

- Al- Barri T. and M. J. Shtaya (2013). Phenotypic characterization of Faba bean Vicia Faba L. landraces grown in Palestine. Journal of Agricultural Science; 5:110-117.

- Alghamdi. S. S. (2007). Genetic Behavior of some selected faba bean genotypes. African crop Science confrance proceeding 8:709-714.

- Alghamdi. S. S. and Kh, A. Ali (2004). Performance of several newly bred faba bean lines. Ehgypt. J. plant breed 8, 189-200.

- Basheer- Salimia. R.; M. Shlaya.; M. Acvad.; J. Abduallah and Y. Hamdan (2013). Genetic diversity of palastine landraces of Faba bean (Vicia faba) bascd on RAPD markers. Genetic and Molecular research 23(3): 3314-3323.

- Bond. DA.; DA. Lawes.; GC. Hawtin.; MC. Saxena and JS. Stephens (1985). Faba bean (Vicia faba L.) In: Sumer field RJ, Roberts EH. Editors, grain legume crops crops and Graftan streed, London, WIX 3LA,UK: William Collins Sone Co. Lid: 1985p. 199-265.

- Daur L.; H. Sepetoglu.; K. B. Marwat and M. N. Gererek (2010). Effect of humic acid on growth 
and quality of maize fodder production. Pakistan journal of botany 2010- 42(5). 3477-3484.

- Hanelt. P. D. Metin (1989). Biosystematics of the genus Vicia faba (Leguminosae) Annual review of ecological system 20:199-223.

- Magda. A. F and H. M. H. Shalaby (2000). Influence of cycocel on the vegetative growth photosynthetic pigments, flowering abscission and yield of faba bean Vicia faba. Annals of Agricultural science moshlohor, 2000, 38, 14851502.

- Sadiki. M.; L. Belaadi.; M. Mehdi and D. Jarvis (2002). Diversity des varieles locales de fereala ferme au maroc : Bas scientifique pour la conservation in situ le devenir des leqqumineuses alimentaires dans le magrheb 2 ${ }^{\text {eme }}$ seminaire du. Tumisie (b) pp.65.

- Sadiki. M.; M. Kharrate and M. E. H. Mautougui (2002). Development d'une collection (CORE) et utilization des resources genetigies locales de Vicia faba au Maghreb less biotechnologies en agriculature et an industrie agroalimentaires. Etats des lieux perspectives morocco-2002 (9)pp.26.

- Sharif. P. (2015). Genetic variation for seed yield and some of agro-morphological traits in faba bean (Vicia faba L.) genotype. Acta agriculturae slovenica 105-1, marec 2015 str. 73-83.
- Sifi. B.; M.; M. Khurrat.; F. MondragoaRodrigues and N. Farinha (2002). Effect de Irrigation de complement sur le rendement et ses composantes chez les feres et le pois chiche. Scientifique tuniso- portugais. Hummamet. Tunisie pp. 284.

- Tageldin. M. H. A. and S. A. S. Mehasen (2004). Faba bean cultivars fertilized with phosphorous assessed for precision and bias of yield estimation techniques and for yield components power and sample size. Annals and Agric. Sc., Moshtohor 42 (3): 975-988.

- Terzopoulos. P. J. and P. J. Bebeli (2008). Genetic diversity analysis of Mediterranean Faba bean Vicia faba L. with ISSR marker. Field crops research 108:39-44; (2-15).

- Thalji. T (2009). The growth and yield of Faba bean Vicia faba under rain fed and irrigated conditions in Jorden. Bio Science research 6 (1), 35-39.

- Tlaat. N. B and A. M. Abdallah (2008). Response of Faba bean Vicia faba to dual inoculation Rhizobium and VA mycorihiza under different levels of $\mathrm{N}$ and $\mathrm{P}$ fertilization. Jornal of applied science research, 4 (9). 1092-1102.

- Ulukan. H.; M. Culer and S. Keskin (2003). A path coefficient analysis of some yield and yield components in Faba bean (Vicia faba L.) genotypes. Pak. J. Biol. Sci 6 (23). 1951-1955.

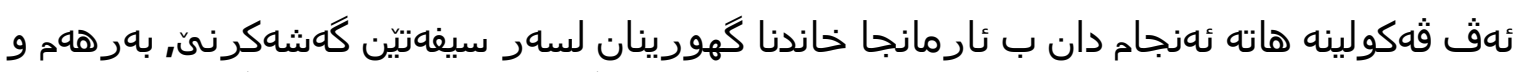

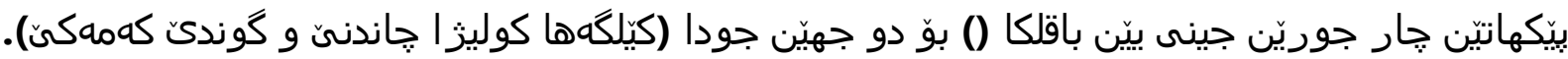

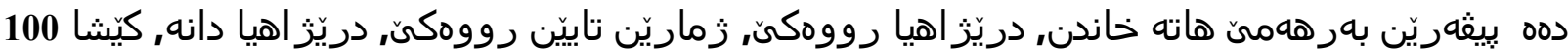

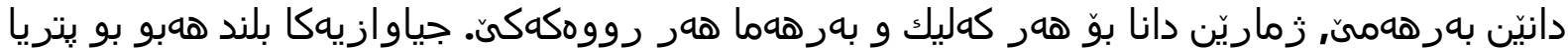

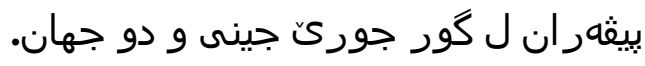

اربعة تر اكيب ور اثية للفول (Vicia faba L. 2n =12) في موقعين مختلفين (حقل كلية المحاصيل

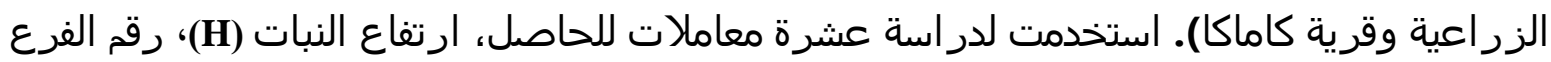

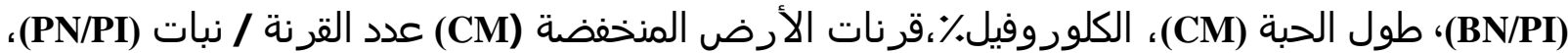

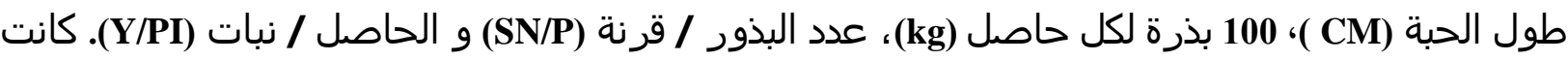

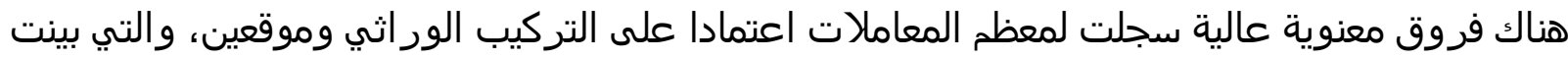

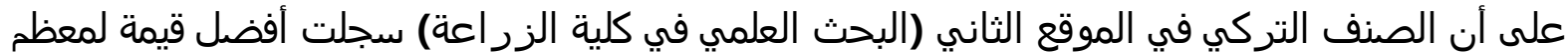

